\title{
La ética como respuesta al sufrimiento inútil en Emmanuel Levinas
}

Analía Giménez Giubbani*

\section{Resumen}

Este artículo tiene como objeto tematizar la cuestión de la ética en Levinas como contestación al sufrimiento inútil. En esencia, se buscará mostrar cómo a través del análisis del sufrimiento el autor llega a la infinitud de la responsabilidad hacia el Otro inscripta en su Rostro, y por tanto a Dios. El primer apartado aborda el problema del mal desde un punto de vista fenomenológico y sus consecuencias; el segundo, se refiere a lo que Levinas denomina el "fin de la teodicea", que deriva de los acontecimientos históricos del siglo xx. Finalmente, de modo más breve, se expone la venida de Dios a la idea a través del encuentro con el Otro y la obligación de responder por su sufrimiento.

\section{Palabras clave}

Sufrimiento, mal, teodicea, Dios, responsabilidad.

Licenciada en Humanidades opción Filosofía. Docente de la Universidad de Montevideo (Uruguay). Miembro Colaborador del Círculo Latinoamericano de Fenomenología. Contacto: agimenez1@correo.um.edu.uy. 


\title{
Ethics as an answer for the senseless pain in Emmanuel Levinas
}

\begin{abstract}
The aim of this article is to theme the ethic matter in Levinas' philosophy as a reply to the senseless pain. Through the analysis of pain the author reaches the infinity of the responsibility to the Other, shown in his/her face, and consequently in God. The first part of this paper deals with the problem of evil from a phenomenological point of view and its consequences; the second part refers to what Levinas calls the "end of theodicy"- which comes from the historical events of the twentieth century. Finally, in a shortened approach, this paper exposes the coming of God to the idea through the meeting with the Other and the duty of giving an answer for his/her suffering.
\end{abstract}

\section{Keywords}

Suffering, evil, theodicy, God, responsibility.

\section{Introducción}

Este artículo tiene como objeto abordar la cuestión de la ética en Levinas como contestación al sufrimiento inútil. Lo que procuro defender es que se puede comprender mejor todo el proyecto filosófico levinasiano si se lo concibe como una respuesta ética al problema del mal $^{1}$. En esencia, se buscará mostrar cómo a través del análisis del

En su estudio introductorio H. Putnam sostiene que la experiencia de la Segunda Guerra en Levinas pudo configurar "su convicción de que lo que se exige de nosotros es la 'infinita' voluntad de estar disponible por y para el sufrimiento del otro". Hilary Putnam, "Levinas y el judaísmo", en Emmanuel Levinas, Difícil libertad: ensayos sobre el judaísmo (Buenos Aires: Editorial Lilmod, 2004), 43. Del mismo modo, R. Bernstein entiende que "el impulso primario del pensamiento de Levinas es su respuesta al horror del mal que hizo erupción en el siglo xx". Richard Bernstein, "Levinas: El mal y la tentación de la teodicea", en El mal radical. Una indagación filosófica, (Buenos Aires: Lilmod, 2004), 234. 
sufrimiento el autor llega a la infinitud de la responsabilidad hacia el Otro inscripta en su Rostro y, por tanto, a Dios.

Levinas se propone "analizar el fenómeno del dolor inútil en la perspectiva interhumana de $m i$ responsabilidad respecto del otro hombre, sin esperanza de reciprocidad, de la exigencia gratuita de auxiliarle, de la asimetría de la relación entre el uno y el otro"'2. El corazón de la filosofía levinasiana es la fórmula de la ética como filosofía primera y el problema del mal -aunque no de manera explícita- tiene un lugar en esta propuesta.

Esta tesis implica aseverar que en Levinas interviene la historia acaecida, lo que se hace inteligible en su texto "El sufrimiento inútil", que tomaremos de guía para esta exposición ${ }^{3}$. La misma se divide en tres secciones que muestran la trayectoria desde el sufrimiento inútil al encuentro con Dios, pasando por la exigente relación ética que me compele a la responsabilidad infinita por el Otro. El primer apartado aborda el problema del mal desde un punto de vista fenomenológico y sus consecuencias; el segundo, se refiere a lo que Levinas denomina el "fin de la teodicea", que deriva de los acontecimientos históricos del siglo xx. Finalmente, de modo más breve, se expone la venida de Dios a la idea a través del encuentro con el Otro y la obligación de responder por su sufrimiento.

\section{El sufrimiento: análisis fenomenológico}

Levinas considera que el sufrimiento no es extraño a la conciencia. Sin embargo, es claro en sostener que aunque "contenido psicológico", se manifiesta como lo inasumible, pese-a-la-conciencia. No es un obstáculo, sino adhesión irreductible "porque el fondo del sufrimiento está hecho de una imposibilidad de interrumpirlo y de un sentimiento agudo de estar clavado"4.

2 Emmanuel Levinas, Entre nosotros. Ensayos para pensar en otro (Valencia: Pretextos, 1993), 125-126.

3 Emmanuel Levinas, "El sufrimiento inútil", en Entre nosotros. Ensayos para pensar en otro, op. cit., 113-126.

$4 \quad$ Emmanuel Levinas, De la evasión (Madrid: Arena, 1999), 79. 


\section{En este sentido, P. Ricoeur sostiene que}

el mal [...] es aquello contra lo que luchamos [...] no tenemos más relación con él que esta relación de «contra». El mal es lo que es y no debería ser, pero de lo que no podemos decir por qué es. Es el no deber ser. Y diría aún esto: el mal es la categoría de lo a pesar de...5.

Levinas pretende mostrar a la conciencia como revulsiva y no como "aprehensión»: el sufrimiento escapa a la comprensión, adoptando la forma del "no-soportar-se". Es el lugar en el que la pasividad significa originalmente, puesto que "en su pese-a-laconciencia, en su mal, el sufrimiento es pasividad [...] es un puro padecer" ${ }^{\prime \prime}$. Padecer la adversidad del sufrimiento, que no significa acogerle en la conciencia activa. Así, en el sufrimiento, la sensibilidad se revela como vulnerabilidad: sufrir es siempre sufrir-se. De este modo, afirma Levinas que "la impotencia o la humildad del "sufrir", está más acá de la pasividad del experimentar. La palabra "sinceridad" toma aquí todo su sentido: descubrirse sin defensa alguna, estar entregado"7.

C. Chalier, en su estudio sobre Kant y Levinas ${ }^{8}$, señala que ambos autores hablan del mal en términos de tentación y de seducción. Pero Levinas no lo califica de necesario y no habla de pecado original, sino que evoca la 'probabilidad' del mal, y sostiene que esta proviene de "la encarnación misma del sujeto"9. Refiriéndose al cuerpo Levinas afirma que

no es sólo un accidente afortunado o desafortunado que nos pone en contacto con el mundo implacable de la materia -su adhesión al Yo vale por sí misma-. Se trata de una adhesión de la que no puede escaparse, y a la que ninguna metáfora podría confundir con la presencia de un

5 Paul Ricoeur, “El escándalo del mal", Revista de Filosofía 3. época IV, 5 (1991): 196.

6 Emmanuel Levinas, Entre nosotros. Ensayos para pensar en otro, op. cit., 116.

7 Emmanuel Levinas, Humanismo del otro hombre (México: Siglo XXI, 2003), 124. En este sentido el autor se pregunta: "¿̇no permanece el espíritu rebelde encerrado en el dolor, ineluctablemente? ¿̀ no es justamente esa desesperación la que constituye el propio fondo del dolor?". Emmanuel Levinas, "Algunas reflexiones sobre la filosofía del hitlerismo", Cuaderno Gris Época III, 5 (2001): 165, http://hdl.handle.net/10486/173.

8 Catherine Chalier, Por una moral más allá del saber. Kant y Levinas (Madrid: Caparrós, 2002).

9 Emmanuel Levinas, Humanismo del otro hombre, op. cit., 107-108. La "encarnación" concebida por Levinas remite a la concepción hebraico-talmúdica. 
objeto exterior. Se trata de una unión cuyo gusto trágico y definitivo nada podrá alterar ${ }^{10}$.

El sujeto experimenta la tentación de separarse del Bien, de desobedecerle y de preferir "el mal seductor y fácil" ${ }^{11}$. Esto no significa que el cuerpo sea malo, sino que el mal y el egoísmo no pueden desaparecer, lo cual estaría esbozando una cierta 'necesidad'. Únicamente el encuentro con la fragilidad del Otro (no unos principios), el sometimiento a la llamada del Rostro, le hace al yo, por un tiempo, deponer las armas, sostiene Chalier. Esta idea de tentación sugiere que se trata para el hombre de una lucha interior constante.

R. Bernstein, por su parte, refiriéndose al artículo "Trascendencia y maldad" de Levinas, describe los "tres momentos de la fenomenología del mal: el mal como exceso, el mal como intención, y el aborrecimiento u horror del mal"12.

Levinas señala que "el mal es un exceso en su esencia misma" y que "todo mal remite al sufrimiento". El mal se experimenta como 'algo' y sin embargo desafía toda categorización, hay algo en él que elude la comprensión y síntesis absolutas, que es la negatividad o el "no" del mal, como "articulación más profunda del absurdo"13, concreción de lo inútil. No es un ataque a la libertad pues "la humanidad del hombre que sufre se halla abrumada por el mal que la desgarra, pero de un modo distinto a como le abruma la no-libertad; de un modo violento y cruel"14. Anticipando una explicación posterior, aquí ya se vislumbra por qué se resiste Levinas a cualquier forma de teodicea. La única respuesta, va a decir, es la ética, que reconoce que soy infinitamente responsable para el Otro, cuyo sufrimiento es más importante que el mío ${ }^{15}$. El exceso del mal, al ser nuestra im-

10 Emmanuel Levinas, "Algunas reflexiones sobre la filosofía del hitlerismo", op. cit., 165.

11 Emmanuel Levinas, Humanismo del otro hombre, op. cit., 108. El mal se muestra como la no aceptación de mis responsabilidades respecto al Otro.

12 Richard Bernstein, "Levinas: El mal y la tentación de la teodicea", op. cit., 243.

13 Emmanuel Levinas, Entre nosotros. Ensayos para pensar en otro, op. cit., 116.

14 Ibíd.

15 Cabe advertir que el sujeto es concebido como para el otro. Levinas no arranca de la unidad del yo para establecer luego la intersubjetividad, sino que invierte este planteamiento. Lo fundacional de mi ser sujeto es la responsabilidad. 
posibilidad de aceptarlo, exige una trascendencia que resplandece en el Rostro del Otro.

Levinas también presenta al mal en su intencionalidad: soy víctima del mal que se me provoca, "me alcanza como si me buscara [...] como si hubiera alguien detrás"16. A partir de esta consideración también podemos arribar al porqué de la tentación de justificar el sufrimiento inútil -teodicea-, tentación que según Levinas debemos resistir.

$Y$, finalmente, el horror del mal, y aquí el origen del mayor impulso de buscar una reconciliación con él, pero a su vez, la revelación de mi asociación con el Bien, más allá del Ser, y la oportunidad de apertura a los demás. El mal no es absoluto, el Bien es anárquicamente anterior; no están en un plano simétrico pues "no se puede plantear un pasaje del Mal al Bien gracias a la atracción de los contrarios. Eso no crearía sino otra teodicea"17 según Levinas.

Dos conceptos importantes surgen de esta "fenomenología del mal": primero, cómo aunque el camino hacia el Bien tenga que atravesar la negatividad del mal y del dolor, hay un lazo, una alianza entre el hombre y el Bien, que liga a un afuera, "anudado sin que el sujeto haya sido voluntad"18. Porque "el horror del mal que apunta hacia mí deviene horror ante el mal en los demás. He aquí un descubrimiento del Bien que no es una simple inversión del Mal sino una elevación [...] que ordena y prescribe"19. Se trata de una adhesión incondicionada al Bien, de un pacto con él, más antiguo que la alternativa del bien y del mal ${ }^{20}$. En espíritu, la experiencia del

Emmanuel Levinas, "Trascendencia y maldad", citado en Richard Bernstein, "Levinas: El mal y la tentación de la teodicea", op. cit., 246.

17 Ibíd., 248. "Ni al lado, ni frente al Bien, sino en el segundo lugar, por debajo, más abajo que el Bien". Levinas, Humanismo del otro hombre, op. cit., 108.

18 Ibíd., 107

19 Emmanuel Levinas, "Trascendencia y maldad", op. cit., 249. Tal "elevación" procede del "mandato divino".

20 Sobre este punto, M. García- Baró afirma que "el ámbito relacional del Bien es el ámbito inmemorial o anárquico, que ha destinado, a priori de todo a priori, el mí-mismo al otro. No es, pues, el otro hombre el Bien, sino la infinitud de la responsabilidad del mí-mismo respecto del otro. Miguel García-Baró, "Filosofía, religión y crisis", Taula, quaderns de pensament, 33-34 (2000): 65, www. raco.cat/index.php/Taula/article/viewFile/71139/90125. 
mal reavivaría la inquietud por el Bien. La Bondad es de este modo la piel última de la subjetividad y aquella alianza se erige mensaje de esperanza, puesto que a pesar de todo el mal está en segundo plano. Pero tal como sostiene C. Chalier

al hablar [...] de afinidad original con el bien, Levinas, evidentemente, no tiene la pretensión de trazar el cuadro de la realidad [...] Lo que quiere decir que, a pesar del terrible oprobio que pesa sobre ella, [...] el alma humana seguirá siendo capaz, de manera imprevisible y graciosa, de oír la llamada del bien ${ }^{21}$.

En segundo lugar, la necesidad de distinguir el sufrimiento en mí y el sufrimiento en otro, puesto que el fenómeno mismo del sufrimiento inútil es el dolor de los otros y, según Levinas, "la justificación del dolor del prójimo es ciertamente el origen de toda inmoralidad"22. Levinas entiende que

se establece una diferencia radical entre el sufrimiento en otro, allí donde él está, que es imperdonable para mí y que me solicita e invoca, y el sufrimiento en mí, mi propia aventura del sufrimiento en la que su inutilidad constitutiva o congénita puede adquirir sentido, el único sentido del que es susceptible el sufrimiento: convertirse en sufrimiento por el sufrimiento -incluso inexorable- de otro ${ }^{23}$.

Esta distinción, tiene que ver con un sujeto de antemano expuesto a la interpelación del Otro. Precisamente, el sufrimiento es humano, cuando se convierte en por-el-Otro, cuando es sufrimiento que ilumina, sufrimiento del amor, expiación ${ }^{24}$. Esta es la "profunda aventura de la subjetividad"25 en la que estoy más cerca de Dios. Este es "el nudo mismo de la subjetividad humana a punto de erigirse en un supremo principio ético -el único incontestable-" ${ }^{26}$. Un imperativo de

21 Catherine Chalier, La utopía de lo humano (Barcelona: Riopiedras, 1995), 121. Tal como sentencia García- Baró "no existe nadie que pueda ser absolutamente sordo a la llamada de la bondad radical". Miguel García- Baró, "La filosofía de la religión como filosofía primera", Daimon Revista de Filosofía, no 39 (2006): 32, http://digitum.um.es/xmlui/bitstream/10201/9151/1/La\%20filosofia\%20 de\%20la\%20religion\%20como\%20filosofia\%20primera.pdf.

22 Emmanuel Levinas, Entre nosotros. Ensayos para pensar en otro, op. cit., 123.

23 Ibíd., 118-119.

24 "Sufrir por el otro, es tenerlo al cuidado, soportarlo, estar en su lugar, consumirse por él [...] misericordia «conmoción de las entrañas»". Emmanuel Levinas, Humanismo del otro hombre, op. cit., 124-125. Emmanuel Levinas, Entre nosotros. Ensayos para pensar en otro, op. cit., 123. Ibíd., 119. 
responder de la miseria del Rostro, imperativo que no he escogido. El Otro me pone bajo el signo del infinito y me concierne "a pesar mío"27 a responder. Levinas se pregunta

el mal del sufrimiento -pasividad extrema, impotencia, abandono y soledad-, ¿̇no es al mismo tiempo lo inasumible y, también, merced a su no integración en un orden y en un sentido, la posibilidad de una curación y, más exactamente, aquella en la que tiene lugar un ruego, un grito, un gemido o un suspiro, demanda de ayuda originaria, petición de un auxilio curativo, un auxilio de otro yo cuya alteridad, cuya exterioridad promete la salvación? ${ }^{28}$.

Se trata de una apertura al auxilio del Otro, y así trascendencia. Porque el sufrimiento solo tiene 'sentido' en lo interhumano: en la prohibición de abandonar al Otro, en la orden que se me dirige para hacerme cargo de su sufrimiento. Levinas recuerda en este punto un diálogo talmúdico que muestra que "el prisionero no puede liberarse solo de su encierro" 29 y ratifica que

la apertura es la vulnerabilidad de una piel ofrecida, en el ultraje y en la herida [...] En la sensibilidad, "se pone al descubierto", se expone un desnudo más desnudo que el de la piel que, forma y belleza, inspira a las artes plásticas; desnudo de una piel ofrecida al contacto, a la caricia que siempre, y aun en la voluptuosidad equívocamente, es sufrimiento por el sufrimiento del otro ${ }^{30}$.

El mal consiste en "la posibilidad de no despertar al otro" y "pertenece al orden del ser en sentido estricto, mientras que, al contrario, el ir hacia el otro es la irrupción de lo humano en el ser, es «de otro modo que ser»"31. El mal se hace equivaler al ser, y en este sentido es muy poderoso; su ley es el interés y la indiferencia respecto de lo otro.

Emmanuel Levinas, Humanismo del otro hombre, op. cit., 110.

Emmanuel Levinas, Entre nosotros. Ensayos para pensar en otro, op. cit., 117.

Ibíd., 118, nota al pie. "Tratado Berakhot del Talmud babilonio, página 5 b. Rav Hiya bar Abba cae enfermo y Rav Yohanan le hace una visita. Le pregunta: -íTe convienen tus sufrimientos? -Ni ellos, ni las recompensas que me prometen- Dame tu mano, dice entonces el visitante al enfermo, y el visitante levanta al enfermo de su lecho. Pero sucede que el propio Rav Yohanan cae enfermo y recibe la visita de Rav Hanina. La misma pregunta: $-\dot{i}$ Te convienen tus sufrimientos? La misma respuesta: -Ni ellos, ni las recompensas que me prometen. -Dame tu mano, dice Rav Junina, y levanta a Rav Yohanan de su lecho. Pregunta: -¿̇No podía Rav Yohanan levantarse solo? Respuesta: -El prisionero no puede liberarse solo de su encierro". Es así que "el hombre libre está consagrado al prójimo, nadie puede salvarse sin los otros". Emmanuel Levinas, Humanismo del otro hombre, op. cit., 131. Ibíd., 122-123.

31 Emmanuel Levinas, Entre nosotros. Ensayos para pensar en otro, op. cit., 140. 
Es el conatus essendi, el impulso en pos de existir y preservarse. Pero según Levinas "lo humano rompe con el puro ser, que siempre es una persistencia del ser. Ésta es mi tesis principal [...] Sin embargo, con la aparición de lo humano, y ésta es íntegramente mi filosofía, hay algo más importante que mi vida: la vida del otro"32. Constituirse como humano es, entonces, trascender esa lógica del ser respondiendo éticamente al sufrimiento del Otro ${ }^{33}$. Adviértase la tesis levinasiana de la primacía del Bien sobre el ser y, por tanto, de la ética por sobre la ontología.

\section{Fin de la teodicea}

Levinas halla que el sufrimiento puede tener una finalidad biológica o una utilidad social, pero que igualmente puede ser alcanzado por el exceso del mal. Enseguida cuestiona: "ino es la experiencia humana el testimonio histórico de la maldad y de la mala voluntad?"34. Según él, al igual que $\mathrm{H}$. Arendt, el mal que estalló durante el período nazi dejó a la moral expuesta, revelando la ineptitud de la ética tradicional para tratar el problema del mal y, de este modo, el nihilismo no es ya un asunto puramente teórico. Levinas concreta la pregunta: “¿no adquiere en los campos de exterminio la declaración de Nietzsche acerca de la muerte de Dios la significación de un hecho casi empírico?"35.

En una entrevista Levinas afirma:

si hay un momento explícitamente judío en mi pensamiento, es la referencia a Auschwitz, donde Dios dejó que los nazis hicieran lo que querían.

"The Paradox of Morality: an Interview with Emmanuel Levinas" en Robert Bernasconi y David Wood (comps.), The provocation of Levinas: Rethinking the Other (Londres: Routledge, 1988), 172. Citado en Richard Bernstein, "El mal y la tentación de la teodicea", op. cit., 249.

33 "El Mesías es el justo que sufre, el que cargó consigo el sufrimiento de los demás. ¿̇uién carga a fin de cuentas sobre sí el sufrimiento de los demás, sino el ser que dice "Yo"? El hecho de no eludir la carga impuesta por el sufrimiento de los otros define la ipseidad como tal. Todas las personas son el Mesías [...] El Mesianismo [...] es mi poder de soportar el sufrimiento de todos". Emmanuel Levinas, Difícil libertad: ensayos sobre el judaísmo, op. cit., 318-319.

34 Emmanuel Levinas, Entre nosotros. Ensayos para pensar en otro, op. cit., 120.

35 Ibíd., 122. Vemos que Levinas se atreve a interpretar un fenómeno sociohistórico. Según él "Auschwitz fue una crisis profunda que concierne a la propia relación del hombre con Dios". Ibíd., 254. Con más intensidad exclama "i1941! -agujero en la historia- año en que todos los dioses visibles nos habían abandonado, en que Dios verdaderamente ha muerto o ha vuelto a su irrevelación". Emmanuel Levinas, Humanismo del otro hombre, op. cit., 54. 
En consecuencia, ¿̇qué queda? Esto significa o bien que no hay motivos para la moral, y por lo tanto se deduce que todos debieran actuar como los nazis, o bien que la ley moral conserva su autoridad. Aquí hay libertad; esta opción es el momento de libertad ${ }^{36}$.

Aludiendo al sufrimiento de los inocentes, Levinas pregunta si aquél no es "testimonio de un mundo sin Dios" y entiende que "hay en la vía que conduce al Dios único, una etapa sin Dios [...] Es el momento en el que Dios se retira del mundo y oculta su rostro". El bien que no llega a triunfar, revela un Dios que apela a la madurez del hombre, completamente responsable; "pero de inmediato ese Dios que oculta su rostro [...] llega desde adentro" ${ }^{\prime 37}$. Levinas no propone renunciar a Dios, sino que convoca a "una fe más difícil que nunca, una fe sin teodicea" ${ }^{\prime 38}$.

En su ensayo "El sufrimiento inútil", el autor declara que estamos viviendo la época después "del fin de la teodicea" ${ }^{39}$. Esta sentencia implica que debemos renunciar al "final feliz", y al "plan de conjunto" utilizado para divisar en el sufrimiento absurdo, un sentido y un orden, puesto que asistimos a la destrucción del equilibrio entre la teodicea y las formas que asumió el mal en el siglo xx. Auschwitz es el "paradigma del sufrimiento gratuito, en el que el mal aparece en su horror diabólico" ${ }^{\prime 4}$, y aunque no es solamente la catástrofe judía lo que el autor destaca, lo que todas muestran es una razón política desprendida de toda ética ${ }^{41}$.

Levinas se refiere a la teodicea en un sentido amplio, al entender que "es tan antigua como cierta lectura de la Biblia [...] explícita

"The Paradox of Morality: an Interview with Emmanuel Levinas", op. cit., 175-176. Citado en Bernstein, "El mal y la tentación de la teodicea", op. cit., 235.

37 Emmanuel Levinas, Difícil libertad: ensayos sobre el judaísmo, op. cit., 172-173. Esto a propósito del "Amar a la Torá más que a Dios" de Yossel ben Yossel.

38 Emmanuel Levinas, Entre nosotros. Ensayos para pensar en otro, op. cit., 124. Sobre la presencia/ ausencia de Dios en Auschwitz, E. Wiesel realiza un examen teológico de la responsabilidad divina, en el que se refiere a "el silencio de Dios", y apunta a dos tipos de experiencia religiosa; la pérdida de fe para algunos que suponía el descubrimiento de Dios para otros. Cf. Elie Wiesel, Legends of our time (New York: Avon, 1968).

39 Emmanuel Levinas, Entre nosotros. Ensayos para pensar en otro, op. cit, 121.

40 Ibíd., 122.

41 Cf. Ibíd., 121. 
en la referencia principal de los cristianos al Pecado Original [...] implícita en el Antiguo Testamento"42. El autor concibe a la teodicea en términos de tentación, que en cualesquiera de sus formas, aspira a hallar algún tipo de justificación al sufrimiento inútil, intentando subordinar el dolor a una "finalidad metafísica adivinada por la fe o por la creencia en el progreso"43, que invocamos para hacer soportables e inteligibles los sufrimientos. Refiriéndose a esta pretensión e interpretando el pensar levinasiano, A. Sucasas acusa una "mercantilización de la experiencia religiosa" en la que "el Mismo egoísta diseña a su medida un dios 'económico' que proporciona al sujeto seguridad en el final y justificación de su sufrimiento presente ${ }^{44 "}$. Asimismo entiende que la teodicea, como "idolatría contable", no hace más que prolongar "teológicamente la voluntad imperialista del Mismo"45.

El discurso de la teodicea, había sido, según Levinas, hasta el siglo xix, "uno de los componentes de la conciencia de sí de la humanidad europea"46, y pese al mal acaecido en el siglo xx, la civilización occidental no cesa en su deseo de buscar una reconciliación con él. Reconciliación "inútil", búsqueda errónea. El autor problematiza y cuestiona si la teodicea logra preservar la inocencia de Dios o salvar la moral, y si consigue hacer el sufrimiento tolerable.

Es así que a partir de las reflexiones del filósofo judío canadiense Émil Fackenheim sobre el genocidio nazi del pueblo judío, y refiriéndose a la inocencia de las víctimas asesinadas y torturadas, entre ellas muchos niños, Levinas concluye que se trata del "dolor en toda su malignidad y sin mezcla, sufrimiento en vano [lo que] hace imposibles y odiosos todos los pensamientos o declaraciones

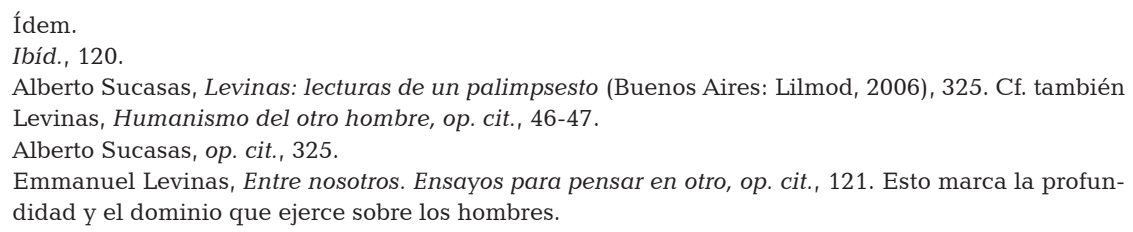


que explicarían el sufrimiento por los pecados de quienes sufrieron o murieron" ${ }^{47}$.

Este "fin de la teodicea", que pone en cuestión la fe y la empresa teológica, "ino revela, al mismo tiempo y de una forma más general, el carácter injustificable del sufrimiento en el otro hombre, el escándalo en que consistiría que yo justificase el sufrimiento de mi prójimo?"48. Yo soy el acusado en esta filosofía que me exhorta al sufrimiento no inútil o amor, "sufrimiento inspirado por el sufrimiento del otro hombre [...] que ya no es sufrimiento en vano y que tiene sentido pleno" ${ }^{\prime 49}$ en la no-indiferencia y la responsabilidad elevada a culpabilidad por el dolor del Otro. Al decir de P. Ricoeur:

si bien tenemos algunas tradiciones bien constituidas en lo que concierne al mal moral, al pecado, no las tenemos en absoluto en lo que respecta al mal padecido, al sufrimiento, o, dicho de otro modo, a la figura del hombre víctima, más que a la del hombre pecador. El hombre pecador da mucho que hablar; el hombre víctima, mucho que callar ${ }^{50}$.

Es, para Levinas, una pregunta seria si la moral es o no una farsa ${ }^{51}$ y el problema filosófico que queda trazado es "el sentido que aún pueden conservar [...] tanto la religiosidad como la moralidad humana de la bondad"52 después del "fin de la teodicea".

H. Arendt también se aventura a desentrañar el fenómeno del totalitarismo y reflexiona sobre el mal radical que "nos enfrenta con su abrumadora realidad y destruye todas las normas que conocemos" ${ }^{\prime \prime 3}$. Después del juicio de Eichmann, la autora se centra en la "banalidad del mal" puesto que este

47

48

Ídem.

Ibíd., 124. La "acusación" indica una dependencia hacia el Otro, derivada de la pasividad constitutiva del ser humano.

50 Paul Ricoeur, op. cit., 191.

51 Cf. Emmanuel Levinas, Totalidad e infinito (Salamanca: Sígueme, 1995), 47.

52 Emmanuel Levinas, Entre nosotros. Ensayos para pensar en otro, op. cit., 123.

53 Hannah Arendt, Los orígenes del totalitarismo (Madrid: Taurus, 1998), 368. La autora juzga que "el mal, en el Tercer Reich, había perdido aquella característica por la que generalmente se le distingue, es decir, la característica de constituir una tentación". Hannah Arendt, Eichmann en Jerusalén. Un estudio acerca de la banalidad del mal (Barcelona: Lumen, 2003), 91. 
puede proliferar y arrasar el mundo entero precisamente porque se extiende como un hongo en la superficie. 'Desafía' al pensamiento, según dije, porque el pensamiento trata de alcanzar alguna profundidad, de ir a la raíz, y en el momento en que se ocupa del mal se ve frustrado porque ahí no hay nada. Tal es su 'banalidad'. Solo el bien tiene profundidad y puede ser radical ${ }^{54}$.

La premisa central de la noción de "banalidad del mal" es la falta de pensamiento, por la que los hombres pueden aceptar irreflexivamente cualquier criterio, renunciando a la responsabilidad de pensar sobre sus actos. El objetivo del totalitarismo es, según Arendt, hacer a los seres humanos superfluos, eliminar su humanidad y destruir su individualidad.

Al referirse a la responsabilidad para con el Otro, la autora cuenta la historia de Anton Schmidt que "estaba al mando de una patrulla que operaba en Polonia, [...] y había ayudado a los guerrilleros judíos, proporcionándoles documentos falsos y camiones del ejército. Y, lo cual es todavía más importante: «No lo hacía para obtener dinero»"55. De esta historia, Arendt extrae algunas impresiones. Por un lado, "cuán distinto hubiera sido todo en esta sala de audiencia, en Israel, en Alemania, en toda Europa, quizá en todo el mundo, si se hubieran podido contar más historias como aquella"56. Por el otro, "la lección es que actitudes cual la que comentamos constituyen cuanto se necesita, y no puede razonablemente pedirse más, para que este planeta siga siendo un lugar apto para que lo habiten seres humanos"57.

\section{Dios y la relación ética}

Esta historia que cuenta Arendt ilustra la forma en que Levinas piensa la responsabilidad infinita hacia los demás. Levinas entiende al sujeto como confinado a responder al Otro hasta el punto de "vaciarse de su ser"58 por él. El sí mismo está encarnado para ofre-

Hannah Arendt, Una visión de la historia judía y otros ensayos (Barcelona: Paidós, 2005), 150. Cercana a Levinas en esta declaración.

55 Hannah Arendt, Eichmann en Jerusalén. Un estudio acerca de la banalidad del mal, op. cit., 139.

56 Ídem.

57 Ibíd., 140.

58 Emmanuel Levinas, De otro modo que ser, o más allá de la esencia (Madrid: Nacional, 2002 ), 149. 
cerse, para sufrir y para dar, incómodo en su piel ${ }^{59}$. Este alcanza la condición humana en esa responsabilidad "que procede de un dios -o de Dios- que lo mira en el rostro del otro ser humano, su prójimo, «lugar» original de la Revelación"60. En el Rostro del Otro, en esta asignación de responsabilidad estoy en relación con Dios, escucho su Palabra, que es ética. Comprendo en el Otro la inscripción de Dios en mí. "Dios viene a la idea" en el encuentro con el prójimo, pero esta experiencia exige como condición indispensable que la moral humana sea su vía fundamental de acceso ${ }^{61}$. Este Dios que viene no es una idea de la razón, ni un principio abstracto, sino Él que manda en la Biblia "No matarás".

La idea de Infinito de Descartes da a Levinas un modelo formal de una relación entre dos términos basado en la asimetría. La relación ética con el otro hombre es la expresión social de este modelo ${ }^{62}$. El Infinito no posee otro contenido más allá de su contenido ético de modo que "la ética es una óptica de lo divino. Ninguna relación con Dios es más directa ni inmediata. Lo Divino no puede manifestarse sino a través del prójimo"63. El estatuto de esa significación encarnada en el Rostro es la huella, que no es sino "la proximidad de Dios en el rostro de mi prójimo"64. Lo humano apunta a lo divino, por tanto el Otro es el comienzo de toda religiosidad.

Cf. Ibíd., 187. “Es necesario pensar en términos más radicales: el otro es siempre el pobre, la pobreza lo define como otro, y la relación con él seguirá siendo siempre ofrenda y don, nunca un acercamiento «con las manos vacías»". Emmanuel Levinas, Difícil libertad: ensayos sobre el judaísmo, op. cit., 285-286.

60 Emmanuel Levinas, "Algunas reflexiones sobre la filosofía del hitlerismo", op. cit., 167. Carta dirigida por Levinas al profesor Davidson y publicada en el Critical Inquiry en otoño de 1990, Vol. XVII, n. ${ }^{\circ}$ 1, p. 62. "Lo que falta a la responsabilidad como principio de individuación humana es quizá que Dios nos ayude a ser responsables; ahí reside la benignidad. Pero para merecer la ayuda de Dios hay que estar dispuesto a hacer lo que hemos de hacer sin ayuda ninguna". Emmanuel Levinas, Entre nosotros. Ensayos para pensar en otro, op. cit, 134.

61 "La experiencia religiosa debe ser primero - por lo menos para el Talmud-, una experiencia moral". Emmanuel Levinas, "Justicia y Perdón", en La propuesta del judaísmo, Bernardo Kliksberg ed. (Caracas: Pensamiento Judío Contemporáneo, 1997), 52.

62 "Hemos llamado a la relación que une el Yo y el Otro idea de lo Infinito". Emmanuel Levinas, $\mathrm{Hu}$ manismo del otro hombre, op. cit., 63.

63 Emmanuel Levinas, Difícil libertad: ensayos sobre el judaísmo, op. cit., 187.

64 Emmanuel Levinas, Entre nosotros. Ensayos para pensar en otro, op. cit., 75. "Sólo un ser que trasciende el mundo -un ser absoluto- puede dejar una huella". Emmanuel Levinas, Humanismo del otro hombre, op. cit., 80. 
Dios nunca aparece como objeto de conocimiento, su trascendencia no puede decirse ni pensarse en términos de $\operatorname{ser}^{65}$. Para Levinas, el ser, en cuanto germen de inteligibilidad, hace a lo trascendente inmanente. Pero es posible un Dios sin la «contaminación del ser»: en el encuentro con el Otro.

Aunque Levinas insiste en que no hace teología sino filosofía, "la venida de Dios a la idea" reclama un desarrollo teológico. El Rostro no es un simple medio para el encuentro con la divinidad, sino su revelación no idolátrica ${ }^{66}$. Se advierte una armonía entre ética y religión puesto que solo desde la vida ética cabe elevarse a la religión. En resumen:

Es en esta preeminencia del otro hombre sobre mi propio yo, más que en mi admiración por la creación y con anterioridad a la búsqueda de la primera causa del universo, como Dios viene a la idea. [...] El «rostro» en su desnudez es la fragilidad de un ser único expuesto a la muerte, pero al mismo tiempo es el enunciado de un imperativo que me obliga a no dejarlo solo.

Dicha obligación es la primera palabra de Dios. La teología comienza, para mí, en el rostro del prójimo. La divinidad de Dios se juega en lo humano. Dios desciende en el rostro del otro. Reconocer a Dios es escuchar su mandamiento: «No matarás», que no se refiere únicamente a la prohibición del asesinato, sino que constituye una llamada a la responsabilidad incesante para con el otro -ser único-, como si yo hubiese sido elegido para esta responsabilidad que me da la posibilidad, también a mí, de reconocerme único, irremplazable, de poder decir: «Yo». Y ello, siendo consciente de que en cada una de mis humanas empresas, de las que el otro nunca está ausente, respondo de su existencia de ser único ${ }^{67}$.

\section{Reflexiones finales}

Para terminar, algunas reflexiones a modo de conclusión, bajo el título: Tú me salvas, porque me invitas a ser.

65 "La huella significa más allá del ser". Ibíd., 75.

66 "Ser a la imagen de Dios, no significa ser el icono de Dios, sino encontrarse en su huella [...] Es ir hacia los Otros que se encuentran en la huella de la eleidad". Ibíd., 82.

67 Emmanuel Levinas, Los imprevistos de la historia, (Salamanca: Sígueme, 2006), 194. 
Ante todo, estar convencidos de que no hay identidad posible sin un Tú que nos reclame. ¿Somos si solo respondemos por nosotros? Lo que nos identifica es nuestra condición de apertura, es la herida que nos expone a los otros, el lugar en el que nos des-centramos y retornamos a nosotros reconociéndonos. La vivencia de ser uno mismo nos revela, con una intensidad desmedida, que no salir al encuentro del Otro es condenarse, arriesgarse a vivir en el exilio de la propia piel, incómodos, sin lugar, ajeno. Nuestra subjetividad es vulnerabilidad. Descubrimos que lo más propio del ser humano es anterior a cualquier decisión y, por lo tanto, anterior también a lo que creímos que era lo más esencial: nuestra libertad. Estamos constitutivamente expuestos, aptos a priori a "ser abatidos". Hechos para el Otro, somos sustitución y expiación. La responsabilidad asumida por el Otro no tiene límites, es así de escandalosa. Salgo de mí al encuentro con el Otro del que asumo soy responsable, incluso de sus propias responsabilidades. De este modo la relación que se entabla es asimétrica, soy responsable sin esperar, y en la medida en que no exista reciprocidad, yo soy sujeción al Otro. El Tú que me invita a des-colocarme para id-entificarme me salva de la incomodidad de mi propio anonimato, de mi propia soledad; sin el Otro me condeno a no ser.

\section{Bibliografía}

Arendt, Hannah. Los orígenes del totalitarismo. Madrid: Taurus, 1998. . Eichmann en Jerusalén. Un estudio acerca de la banalidad del mal. Barcelona: Lumen, 2003.

. Una visión de la historia judía y otros ensayos. Barcelona: Paidós, 2005.

Bernstein, Richard. "Levinas: el mal y la tentación de la teodicea". En El mal radical. Una indagación filosófica, 233-254. Buenos Aires: Lilmod, 2004. 
Chalier, Catherine. Por una moral más allá del saber. Kant y Levinas. Madrid: Caparrós, 2002.

. La utopía de lo humano. Barcelona: Riopiedras, 1995.

García-Baró, Miguel. "Filosofía, religión y crisis". Taula quaderns de pensament, 33-34 (2000): 51-70, www.raco.cat/index.php/Taula/ article/viewFile/71139/90125 (consultada en enero 27, 2012).

. "La filosofía de la religión como filosofía primera". Daimon Revista de Filosofía n ${ }^{\circ} 39$ (2006): 29-39, http://digitum. um.es/xmlui/bitstream/10201/9151/1/La\%20filosofia\%20 de\%20la\%20religion\%20como\%20filosofia\%20primera.pdf (consultada en enero, 27, 2012).

Levinas, Emmanuel. Difícil libertad: ensayos sobre el judaísmo. Buenos Aires: Lilmod, 2004.

. "Algunas reflexiones sobre la filosofía del hitlerismo". Cuaderno Gris Época III, 5 (2001): 161-167, http://hdl.handle. net/10486/173 (consultada en enero 27, 2012).

. Entre nosotros. Ensayos para pensar en otro. Valencia: Pretextos, 1993.

. De la evasión. Madrid: Arena, 1999.

. Humanismo del otro hombre. México: Siglo XXI, 2003.

. Totalidad e infinito. Salamanca: Sígueme, 1995.

. De otro modo que ser, o más allá de la esencia. Madrid: Nacional, 2002.

. "Justicia y Perdón". En La propuesta del judaísmo, editado por Bernardo Kliksberg, 52-57. Caracas: Pensamiento Judío Contemporáneo, 1997.

. Los imprevistos de la historia. Salamanca: Sígueme, 2006.

Putnam, Hilary. "Levinas y el judaísmo". En Emmanuel Levinas, Difícil libertad: ensayos sobre el judaísmo, 43-77. Buenos Aires: Lilmod, 2004. 
Ricoeur, Paul. "El escándalo del mal". Revista de Filosofía 3. ${ }^{a}$ época IV, 5 (1991): 191-197, www.ucm.es/BUCM/revistas/ fsl/00348244/articulos/RESF9191120191A.PDF

Sucasas, Alberto. Levinas: lecturas de un palimpsesto. Buenos Aires, Lilmod, 2006.

Wiesel, Elie. Legends of our time. New York: Avon, 1968.

Enviado: enero de 2012 Aceptado: abril de 2012 